\title{
INTERPRETIVE SUMMARIES, MAY 2013
}

Characterization and stability of lactobacilli and yeasts microbiota in kefir grains. By Vardjan et al., page 2729. Characterization and stability of lactobacilli and yeasts from kefir grains were investigated. Culture-dependent methods revealed 3 predominant lactobacilli and 3 predominant yeasts species, whereas culture independent methods revealed only 1 lactobacilli and 2 yeasts species. This result confirms that only predominant lactobacilli and yeast populations in kefir grains could be identified. Therefore, the combination of both techniques is necessary for detailed and reliable study of microbial communities in kefir grains. Another interesting finding confirmed that the microbiota of kefir grains is very stable. This finding is important to ensure consistent product quality.

http://dx.doi.org/10.3168/jds.2012-5829.

Evaluation of the Charm maximum residue limit $\beta$-lactam test for the detection of antibiotics in ewe and goat milk. By Beltran et al., page 273\%. The Charm MRL BLTET test (Charm Sciences Inc., Lawrence, MA) is an immunoreceptor assay that detects $\beta$-lactam and tetracycline drugs in raw commingled cow milk at or below European Union maximum residue limits (EU-MRL). To assess the Charm MRL BLTET test for the detection of $\beta$-lactams and tetracyclines in small ruminant milk, an evaluation study was performed according to Commission Decision 2002/657/EC. Specificity results (false-positive rate and cross-reaction) were optimal for ewe and goat milk. The calculated detection capability was at or below EU-MRL for most $\beta$-lactams and tetracyclines tested. Acidiol had no effect on the performance of the test. Therefore, the Charm MRL BLTET test could be used routinely for the rapid screening of ewe and goat milk.

http://dx.doi.org/10.3168/jds.2012-6044.

Conditions associated with Clostridium sporogenes growth as a surrogate for Clostridium botulinum in nonthermally processed canned butter. By Taylor et al., page 2754. Canned butter has been suggested as a shelf-stable lipid source for longterm food storage. However, the safety of the product is in question because it does not undergo thermal processing and thus could result in botulism. For this study, butter with different salt contents was produced from cream inoculated with Clostridium sporogenes before canning. Bacterial growth in hermetically sealed containers of butter was monitored after incubated storage to determine the potential for supporting clostridial outgrowth.

http://dx.doi.org/10.3168/jds.2012-6209.

Volatiles and sensory evaluation of goat milk cheese Gokceada as affected by goat breeds
(Gokceada and Turkish Saanen) and starter culture systems during ripening. By Hayaloglu et al., page 2765. Gokceada goat milk cheeses were manufactured using different breeds (Gokceada and Turkish Saanen) and starter culture systems (starter-free, thermophilic and mesophilic starters) and ripened for $90 \mathrm{~d}$. Volatile composition was determined by using a solid-phase microextraction/gas chromatography mass spectrometric method during ripening at 30-d intervals. Sensory evaluation of 90-d-old cheeses was performed by expert panels who were familiar with goat cheese taste and odor. Milk from the Gokceada breed and mesophilic starter resulted in more satisfactory scores in terms of sensory evaluation and volatile fractions.

http://dx.doi.org/10.3168/jds.2012-6170.

Physicochemical properties of Scamorza ewe milk cheese manufactured with different probiotic cultures. By Albenzio et al., page 2781. Considering that pasta filata cheeses represent the largest cheese segment worldwide, the market of ovine dairy products could benefit from the production of Scamorza ewe milk cheese. This study was undertaken to produce functional Scamorza cheese from Gentile di Puglia ewe milk by incorporating probiotic strains into the cheese matrix and to evaluate the maturing characteristics of Scamorza cheese. The use of probiotic strains could discriminate the maturing profile of Scamorza ewe milk cheese on the basis of its amino acids and fatty acid patterns and might play a role in defining cheese nutritional and functional attributes.

http://dx.doi.org/10.3168/jds.2012-6218.

Composition and sensory profiling of probiotic Scamorza ewe milk cheese. By Albenzio et al., page 2792. Probiotic Scamorza cheese from ewe milk was characterized for the principal chemical composition and sensory properties. A chemical reference range for this pasta filata cheese typology was defined. A specific quantitative vocabulary for Scamorza cheese sensory analysis and a specific reference frame for assessor training was implemented. Texture and appearance attributes were able to differentiate Scamorza cheese containing probiotic bacteria. In particular, incorporating a mix of Bifidobacterium longum BL-46 and Bifidobacterium lactis $\mathrm{BB}-12$ resulted in the greatest differences with the control product in terms of texture and appearance, whereas the incorporation of Lactobacillus acidophilus LA-5 produced intermediate characteristics. http://dx.doi.org/10.3168/jds.2012-6273.

Antigenicity and functional properties of $\beta$-lactoglobulin conjugated with fructo-oligosaccharides in relation to conformational changes. By Zhong et al., page 2808. Our previous research indi- 
cated that the changes of antigenicity of $\beta$-lactoglobulin ( $\beta$-LG) subjected to dynamic high-pressure microfluidization were related to its conformational changes. The present study was undertaken in an attempt to unravel further the relationship among antigenicity, functional properties, and conformation of $\beta$-LG after conjugation with oligosaccharides. The aim of this work was to evaluate the conformational changes of $\beta-\mathrm{LG}$ conjugated with fructo-oligosaccharides and to relate these changes to the antigenicity and functional properties of $\beta-\mathrm{LG}$. http://dx.doi.org/10.3168/jds.2012-6259.

Short communication: Possible mechanism for inhibiting the formation of polymer originated from 5-hydroxymethyl-2-furaldehyde by sulfite group in dairy thermal process. By Guan et al., page 2826. A sulfite group can significantly inhibit the formation of higher molecular weight polymer originated from 5-hydroxymethyl-2-furaldehyde (HMF). Two main reasons have been suggested to explain this phenomenon. The first is that the nucleophilic reaction between a sulfite group and a carbonyl group may inhibit the formation of HMF dimer (one of the main precursors of polymers). The second might be a competitive reaction when 1,2-enolization is performed, which reduces the formation of HMF.

http://dx.doi.org/10.3168/jds.2012-6056.

Technical note: Development and validation of an ulta performance liquid chromatography coupled with tandem mass spectrometry for determination of vitamin $B_{12}$ concentrations in milk and dairy products. By Zironi et al., page 2832. The aim of the study was to develop a method to measure vitamin $B_{12}$ in raw milk and to evaluate its fate along the process of cheese making. The proposed method provides a fast and reliable determination and could be a useful tool to test possible zootechnical strategies aimed at obtaining milk with higher vitamin $\mathrm{B}_{12}$ content or at studying the effects of heat treatments and transformation processes on cobalamins.

http://dx.doi.org/10.3168/jds.2012-6451.

Timing of prostaglandin $F_{2 \alpha}$ treatment in an estrogen-based protocol for timed artificial insemination or timed embryo transfer in lactating dairy cows. By Pereira et al., page $283 \%$. Increased circulating progesterone $(\mathrm{P} 4)$ near the time of AI reduces fertility. In lactating dairy cows, increasing the interval from prostaglandin $F_{2 \alpha}$ treatment to timed AI increased the proportion of cows with lower $\mathrm{P} 4$ and increased the pregnancy to timed AI (TAI) and to timed embryo transfer (TET). The fertility benefits of earlier prostaglandin $\mathrm{F}_{2 \alpha}$ treatment were more dramatic for TAI than for TET, indicating substantial beneficial effects on gamete transport or fertilization as well as smaller but important effects on uterine or hormonal environment, which manifests itself after TET.

http://dx.doi.org/10.3168/jds.2012-5840.

The effect of meloxicam on pain sensitivity, rumination time, and clinical signs in dairy cows with endotoxin-induced clinical mastitis. By Fitzpatrick et al., page 284\%. Clinical mastitis was induced in 24 cows by intramammary infusion of Escherichia coli lipopolysaccharide (LPS). One-half of the cows were treated with meloxicam. Udder pain sensitivity, as measured by a pressure algometer, increased after mastitis induction in control animals but not in meloxicam-treated animals. Overall, rumination time was reduced in the hours following infusion. Meloxicam-treated animals had less udder edema, and lower body temperature in the hours following LPS infusion as compared with control animals. Pressure algometers and rumination loggers show promise as tools to monitor mastitis on farm. Further, meloxicam has beneficial effects in treating clinical signs of endotoxin-induced mastitis.

http://dx.doi.org/10.3168/jds.2012-5855.

Differentiation of Staphylococcus aureus and Staphylococcus epidermidis by PCR for the fibrinogen binding protein gene. By Sunager et al., page 285\% Rapid and accurate identification of bacteria is important for understanding pathogenesis as well as to implement control or eradication programs for mastitis. Subclinical mastitis is frequently caused by staphylococci of which Staphylococcus aureus and Staphylococcus epidermidis are involved to a significant extent. This study describes the application of a multiplex polymerase chain reaction for the identification and differentiation of Staphylococcus aureus and Staphylococcus epidermidis. Although the test was only moderately sensitive, it could accurately and reproducibly detect the 2 species in milk under controlled laboratory conditions even when present among a mix of several other bacteria.

http://dx.doi.org/10.3168/jds.2012-5862.

Enterotoxin genes in coagulase-negative and coagulase-positive staphylococci isolated from bovine milk. By de Freitas Guimarães et al., page 2866. Staphylococcal poisoning caused by enterotoxins is of major concern in public health. Although Staphylococcus aureus has been considered the main species associated with food poisoning, identification of other toxin-producing species would be important to protect public health. The objective was to study the distribution of staphylococcal species causing bovine mastitis in Brazilian dairy herds, and their potential to produce enterotoxins. It was observed that a greater percentage of coagulase-negative staphylococci carried enterotoxin genes compared with Staph. aureus. Identification of 
risk factors for production of enterotoxins by such species should be considered.

http://dx.doi.org/10.3168/jds.2012-5864.

Effect of treatment with human chorionic gonadotropin on day 5 after timed artificial insemination on fertility of lactating dairy cows. By Nascimento et al., page 2873. Ovulation of a day 5 follicle with human chorionic gonadotropin (hCG) can produce an accessory corpus luteum, increase progesterone, and potentially increase fertility. We did a meta-analysis of 10 previous trials using hCG $(\mathrm{n}=4,397)$ and a field trial on 6 herds $(\mathrm{n}=2,979)$ to evaluate $\mathrm{hCG}$ following artificial insemination (AI) on fertility of dairy cows. Pregnancy rates were increased by $\mathrm{hCG}$ in the meta-analysis $(3.0 \%)$ and in the field trial (3.5\%). Surprisingly, the positive effect in the field trial was only found in primiparous cows.

http://dx.doi.org/10.3168/jds.2012-5895.

Concentrations of hormones and metabolites in cerebrospinal fluid and plasma of dairy cows during the periparturient period. By Laeger et al., page 2883. Hormones and metabolites act as satiety signals in the brain and play an important role in the control of feed intake. These signals can reach the hypothalamus and brainstem, 2 major centers of feed intake regulation, via cerebrospinal fluid (CSF). The aim of this study was to elucidate concentrations of satiety signals in CSF and plasma during the periparturient period of dairy cows. The concentration of glutamine in the CSF tended to increase until calving, whereas $\beta$-hydroxybutyrate and leucine concentrations were increased in early lactation compared with the preparturient period. Therefore, these metabolites might be involved in central anorexigenic signaling around parturition.

http://dx.doi.org/10.3168/jds.2012-5909.

The effect of a topical anesthetic on the sensitivity of calf dehorning wounds. By Espinoza et al., page 2894. An experiment was conducted to investigate the effect of a novel topical anesthetic on the sensitivity of dehorning wounds in young dairy calves. Sensitivity was assessed using von Frey monofilaments, which exerted pressure on the dehorned area. Responses were scored before and up to $24 \mathrm{~h}$ after dehorning. Calves treated with the topical anesthetic were less responsive to stimulation up to at least $1.5 \mathrm{~h}$ after dehorning. This suggests the topical anesthetic can provide short-term pain relief.

http://dx.doi.org/10.3168/jds.2012-5954.

Proteomic analysis of differentially expressed proteins in caprine milk during experimentally induced endotoxin mastitis. By Olumee-Shabon et al., page 2903. The goal of the study was to identify proteins present in goat milk before and during experimentally induced endotoxin mastitis. Protein expression patterns in skim milk collected from goats before and following intramammary challenge with purified endotoxin were compared using 2-dimensional gel electrophoresis. Gel spots were excised and peptides from proteins in milk samples from all goats were identified by sequencing using nano-flow liquid chromatography coupled with tandem mass spectrometry. The results provide a preliminary proteomic analysis of goat milk proteins and give new insight into protein changes in goat milk during disease.

http://dx.doi.org/10.3168/jds.2012-5956.

Perinatal, neonatal, and rearing period mortality of dairy calves and replacement heifers in France. By Raboisson et al., page 2913. Calf and heifer mortality represents an economic loss to the dairy industry and is considered a welfare issue. This study revealed that mortality rates in French dairy calves and heifers are low to moderate, based on exhaustive data and classification according to sex and age. It identifies some factors associated with mortality such as sex, breed, season, and dairy production area. Beyond the average mortality rates, the broad range of mortality values shows that some farmers achieve very low mortality, even in animals such as beef-crossed dairy calves for which the mortality risk is known to be high.

http://dx.doi.org/10.3168/jds.2012-6010.

Prevalence of subclinical ketosis and relationships with postpartum diseases in European dairy cows. By Suthar et al., page 2925. Negative energy balance and metabolic challenges during the transition period in dairy cows provoke metabolic and infectious diseases during the first 3 wk postpartum. Subclinical ketosis is one of the common metabolic disorders and considered a gateway condition for postpartum diseases. This observational study from 528 farms across 10 European countries demonstrated that prevalence of subclinical ketosis during the first $15 \mathrm{~d}$ in milk ranged from 11.2 to $36.6 \%$ and was associated with subsequent metabolic and infectious diseases such as metritis, clinical ketosis, lameness, and displaced abomasum.

http://dx.doi.org/10.3168/jds.2012-6035.

Association between somatic cell count early in the first lactation and the longevity of Irish dairy cows. By Archer et al., page 2939. Reduced longevity of cows is an important component of mastitis costs. In this study, an association was shown for SCC between 5 and $30 \mathrm{~d}$ in milk during parity 1 (SCC1), and risk of disposal from the herd. To investigate the effect of the results for particular herd scenarios, an economic simulation that included uncertainty in parameters was conducted. This revealed that the potential savings in 
replacement costs, following an achievable reduction in the herd level prevalence of cows with SCC1 $\geq 400,000$ cells $/ \mathrm{mL}$, were small and suggested that other costs (such as change in lifetime milk yield) should be investigated.

http://dx.doi.org/10.3168/jds.2012-6115.

Somatic cell count early in the first lactation and lifetime milk yield of cows in Irish dairy herds. By Archer et al., page 2951. Lifetime milk yield of Irish dairy cows was shown to be negatively associated with SCC between 5 and $30 \mathrm{~d}$ in milk during parity 1 (SCC1). Potential differences in gross margin between herds with varying prevalence of cows with SCC1 $\geq 400,000$ cells $/ \mathrm{mL}$ were used to demonstrate the scale and likelihood of savings from interventions to control mastitis in prepartum heifers. For herds with $\geq 20 \%$ prevalence of cows with SCC1 $\geq 400,000$ cells/ $\mathrm{mL}$, a reduction to $<5 \%$ prevalence was associated with a $75 \%$ chance of a saving of at least $€ 115 /$ heifer calved into the herd.

http://dx.doi.org/10.3168/jds.2012-6294.

Long-term elevation of $\beta$-hydroxybutyrate in dairy cows through infusion: Effects on feed intake, milk production, and metabolism. By Zarrin et al., page 2960. Effects of an induced hyperketonemia for $48 \mathrm{~h}$ on metabolic variables in plasma and liver of mid-lactating dairy cows were studied. We infused Na-DL- $\beta$-OH-butyrate intravenously to obtain a plasma $\beta$-hydroxybutyrate (BHBA) concentration above 1.5 $\mathrm{mmol} / \mathrm{L}$, comparable to a spontaneous hyperketonemia but not caused by a lack of energy and glucose such as in early lactation. Milk yield and feed intake did not change during BHBA infusion; plasma glucose concentration decreased during the infusion. The decreased glucose concentration could not be explained by alterations of insulin or enzymes related to gluconeogenesis, but was likely functionally related to the observed decrease in plasma glucagon concentration.

http://dx.doi.org/10.3168/jds.2012-6224.

Therapy of bovine endometritis with prostaglan$\operatorname{din} \mathbf{F}_{2 \alpha}$ : A meta-analysis. By Haimerl et al., page 2973. A systematic and evaluative literature review (i.e., meta-analysis) uncovered a shortage of comparable and high quality studies investigating reproductive performance after prostaglandin $\mathrm{F}_{2 \alpha}$ treatment of cows with chronic endometritis. The meta-analysis did not reveal an improvement of reproductive performance after this frequently utilized treatment. Therefore, prostaglandin $\mathrm{F}_{2 \alpha}$ cannot be recommended as the treatment of choice for chronic endometritis.

http://dx.doi.org/10.3168/jds.2012-6154.

Effect of different dry period lengths on milk production and somatic cell count in subsequent lactations on commercial Dutch dairy herds. By Steeneveld et al., page 2988. The effect of the application of no dry period on commercial dairy herds resulted in a reduction in milk production ranging between 3.2 and $9.1 \mathrm{~kg} / \mathrm{d}$. Six herds applied a cow-specific approach with different preplanned dry period lengths. In these 6 herds, a dry period length ranging between 0 and 20 $\mathrm{d}$ resulted in the lowest milk production. We found no difference in somatic cell count postpartum for cows with different dry period lengths.

http://dx.doi.org/10.3168/jds.2012-6297.

Dietary glutamine enhances immune responses of dairy cows under high ambient temperature. By Caroprese et al., page 3002. The study aimed to evaluate the effects of dietary glutamine, administered alone or in combination with flaxseed, in dairy cows under high ambient temperature on milk yield and composition, immune functions, and cytokine production. Glutamine administration increased milk, fat, protein, and casein yields. Furthermore, glutamine was able to sustain the cows' immune reactions, especially by strengthening their cell-mediated immune responses, which are typically decreased in cows under heat stress. Glutamine administration in combination with flaxseed did not further improve the demonstrated positive effects of flaxseed administration on milk yields and fat profile and resulted in a reduction of immunological reactivity. http://dx.doi.org/10.3168/jds.2012-6306.

Depleted serum vitamin E concentrations precede left displaced abomasum in early-lactation dairy cows. By Qu et al., page 3012. To determine the association between vitamin $\mathrm{E}$ status and left displaced abomasum, serum vitamin E concentrations were measured between -3 and 7 wk postpartum in multiparous cows that developed left displaced abomasum in early lactation and were compared with those in healthy cows. Lower vitamin E concentrations preceded and persisted after left displaced abomasum, indicating lower serum $\alpha$-tocopherol concentrations as a potential early indicator for developing left displaced abomasum. http://dx.doi.org/10.3168/jds.2012-6357.

Short communication: Hair cortisol levels in Holstein-Friesian and crossbreed $\mathbf{F}_{1}$ heifers. By Peric et al., page 3023. Crossbreeding produces animals that seem more resilient compared with parental breeds. Crossbreeding may also affect the activation of the hypothalamic-pituitary-adrenal axis (HPA), which results in a hormonal response that aids in achieving maintenance of homeostasis. Cortisol is an endpoint in the investigation of HPA axis function and is routinely determined from blood, feces, urine, milk and saliva. Hair cortisol analysis is a complementary means of monitoring the HPA axis, as it reflects cortisol secretion 
over longer periods. This result helps us to better understand the differences in HPA activity and allostatic load between Holstein-Friesian and crossbreed heifers http://dx.doi.org/10.3168/jds.2012-6151.

Short communication: Comparison of the effects of heat stress on milk and component yields and somatic cell score in Holstein and Jersey cows. By Smith et al., page 3028. This study evaluated the response of Holstein and Jersey cows to heat stress, as measured by milk yield, milk components, and somatic cell score. Jersey cows responded better to mild heat stress by increasing yield and fat-corrected milk but were not different from Holsteins under severe heat stress. Holstein cows still produced more milk and fatcorrected milk than Jersey cows. Breed had no effect on somatic cell score. The relationship between heat stress and somatic cell score was indeterminate.

http://dx.doi.org/10.3168/jds.2012-5737.

Short communication: Minimum bactericidal concentration of disinfectants evaluated for bovine digital dermatitis-associated Treponema phagedenis-like spirochetes. By Dopfer et al., page 3034. This paper presents a protocol for determining the minimum inhibitory concentration and minimum bactericidal concentration of disinfectants for Treponema microorganisms, bacteria implicated in the etiology of bovine digital dermatitis. This protocol can be used for evaluation of potential hoofbath disinfectants to improve the control and prevention of bovine digital dermatitis, a worldwide disease with severe economic impact.

http://dx.doi.org/10.3168/jds.2012-5994.

Short communication: Experimentally induced mastitis reduces weight shifting between the rear legs while standing in dairy cows. By Chapinal et al., page 3039. Clinical mastitis was induced in 10 primiparous and 9 multiparous lactating dairy cows by intramammary infusion of Escherichia coli lipopolysaccharide (LPS) into the right rear quarter. Four hours later, 10 animals received flunixin meglumine intravenously and 9 received a saline solution. Animals treated with flunixin meglumine had lower temperature $7 \mathrm{~h}$ after LPS infusion than did nontreated animals. Overall, weight shifting between the rear legs was decreased 7 $\mathrm{h}$ after the LPS infusion compared with the baseline, likely a measure to avoid friction between the swollen udder and the legs. Treatment did not counteract the decrease in weight distribution.

http://dx.doi.org/10.3168/jds.2012-6397.

Effects of prepartum controlled-energy wheat straw and grass hay diets supplemented with starch or sugar on periparturient dairy cow performance and lipid metabolism. By Litherland et al., page 3050. Effects of forage source [wheat straw
(WS) vs. grass hay (GH)] and supplemental carbohydrate source (starch vs. sugar) on periparturient performance were tested. Prepartum diets contained either $30 \% \mathrm{WS}$ or GH and were supplemented with $6.3 \%$ diet dry matter from ground corn-based dry feed (DF) or cane molasses-based liquid feed (LF). Cows were fed supplement $42 \mathrm{~d}$ prepartum to $56 \mathrm{~d}$ postpartum. Diets with GH had greater prepartum energy balance than diets with WS. Cows maintained dry matter intake (DMI) at $2.0 \%$ of body weight until calving. Milk yield tended to be higher for WS compared with GH, and WS also had lower postpartum nonesterified fatty acids and higher liver glycogen and tended to have lower liver triglyceride:glycogen. Sugar decreased postpartum DMI and energy balance compared with starch but did not affect milk or $3.5 \%$ fat-corrected milk yields, resulting in an increase in feed efficiency ( $\mathrm{kg}$ of $3.5 \%$ fat-corrected milk per $\mathrm{kg}$ of DMI consumed).

http://dx.doi.org/10.3168/jds.2012-5998.

Availability to lactating dairy cows of methionine added to soy lecithins and mixed with a mechanically extracted soybean meal. By Brake et al., page 3064. We evaluated the ability of methionine added to soy lecithins and then mixed with a mechanically extracted soybean meal to escape ruminal destruction. Lactational performance and plasma concentrations of methionine were unaffected by supplementation with methionine added to soy lecithins and mixed with a mechanically extracted soybean meal. Rapid destruction of methionine provided in this fashion was observed in vitro. For the product that we evaluated, methionine did not seem to be ruminally protected when mixed with soy lecithins and applied to a mechanically extracted soybean meal.

http://dx.doi.org/10.3168/jds.2012-6005.

The effect of an exogenous amylase on performance and total-tract digestibility in lactating dairy cows fed a high-byproduct diet. By McCarthy et al., page 3075. High variability in corn prices has increased interest in feeding reduced starch diets containing less expensive byproduct feeds. However, partially replacing corn in the diet with byproducts generally decreases the dietary energy and subsequent milk production. The objectives of this trial were to determine lactation performance and diet digestibility in dairy cows fed a high byproduct diet with or without the addition of exogenous amylase. We hypothesized that amylase would increase diet digestibility to increase the energy feeding value of high byproduct diets. Although exogenous amylase increased diet digestibility, no milk production benefit was observed in this trial.

http://dx.doi.org/10.3168/jds.2012-6045.

Effects of varying forage particle size and fermentable carbohydrates on feed sorting, ru- 
minal fermentation, and milk and component yields of dairy cows. By Maulfair and Heinrichs, page 3085. This experiment studied the interactions between forage particle size and ruminally fermentable carbohydrates on ration sorting, ruminal fermentation, chewing activity, and milk yield and components. We observed a tendency for forage length to increase rumen $\mathrm{pH}$ and starch availability to decrease rumen $\mathrm{pH}$. Intake decreased with increased forage particle size. Fermentable carbohydrate level increased milk yields and components except for fat level which decreased. Fermentable carbohydrates had a greater effect than particle size on cows in this study.

http://dx.doi.org/10.3168/jds.2012-6048.

Relationships between residual feed intake, average daily gain and feeding behavior in growing dairy heifers. By Green et al., page 3098. Feeding behavior was measured in 1,049 Holstein-Friesian heifers from 5 to 9 mo of age during selection for divergent residual feed intake, to identify efficient and inefficient individuals. Heifers were fed alfalfa cubes and the most efficient ate less, spent less time eating, ate more slowly, and had fewer, longer meals than the least efficient, and also ate less in the afternoon but spent more time eating at night. Feeding behavior was weakly associated with residual feed intake, and selection of efficient animals is unlikely to have negative effects on animal management.

http://dx.doi.org/10.3168/jds.2012-6087.

Regulation of bovine adipose tissue metabolism during lactation. 7. Metabolism and gene expression as a function of genetic merit and dietary energy intake. By Rocco and McNamara, page 3108. Regulation of adipose tissue metabolism in transition dairy cattle as a function of genetic merit and dietary energy intake. Sire genetic merit and dietary energy intake affect rates of adipose tissue metabolism in the transition period. The adaptations are dynamic, rapidly adjusting over relatively short periods in response to dietary energy intake and milk production. Control of adipose tissue lipogenesis is highly related to gene transcription of key proteins, whereas lipolysis is not. For lipolysis, regulation likely occurs through posttranslational modification. This knowledge can be used to improve our models of metabolism in dairy cattle to improve productive efficiency.

http://dx.doi.org/10.3168/jds.2012-6097.

In situ protein degradation of alfalfa and birdsfoot trefoil hays and silages as influenced by condensed tannin concentration. By Coblentz and Grabber, page 3120. Inefficient use of crude protein (CP) in forage legumes by ruminant livestock often increases both protein supplementation costs and $\mathrm{N}$ losses from farms. Condensed tannins expressed naturally or via genetic engineering in forages may improve the efficiency of protein use by limiting proteolysis during forage conservation and ruminal fermentation. In this study, 12 hays and 12 silages from alfalfa and birdsfoot trefoil were analyzed for condensed tannin content and evaluated for ruminal disappearance kinetics of CP. Regression analyses of the data indicate that a typical mid-maturity forage legume containing $21 \% \mathrm{CP}$ would require $3.8 \%$ of condensed tannins on a dry matter basis to reduce rumen degradable protein in hay and silage from $81 \%$ to the $70 \%$ target proposed as optimal for dairy cattle.

http://dx.doi.org/10.3168/jds.2012-6098.

Assessment of heifer grazing experience on short-term adaptation to pasture and performance as lactating cows. By Lopes et al., page 3138. Our objective was to determine how grazing experiences early in life affect behavior and milk production of primiparous cows grazing high-quality pastures. Four groups of dairy heifers were assigned to different grazing experiences. Subsequent grazing behavior monitored by GPS and performance as primiparous cows were then compared. Prior grazing experience affected distance walked, time spent grazing, and milk production of primiparous cows during the first week of exposure to pasture. After this time, production and grazing activities were similar for cows with and without previous grazing experience as heifers.

http://dx.doi.org/10.3168/jds.2012-6125.

Evaluation of acidified, ad libitum milk replacer programs for dairy calves. By Hill et al., page 3153. Calves fed acidified milk replacer for ad libitum consumption consumed more milk replacer and had greater body weight gain preweaning but less gain postweaning, resulting in little difference in total body weight gain or feed efficiency from 0 to $112 \mathrm{~d}$ compared with calves fed $0.66 \mathrm{~kg}$ (dry matter) daily of nonacidified milk replacer powder (control). Acidification to $\mathrm{pH} 4.2$ versus 5.2 resulted in some calves refusing to drink the milk replacer and less total consumption. Calves fed ad libitum consumed $95 \%$ of their milk replacer between 0600 and $0800 \mathrm{~h}$ and between 1600 and $1800 \mathrm{~h}$ with no change in standing time per day compared with the control.

http://dx.doi.org/10.3168/jds.2012-6132.

Rumen passage kinetics of forage and concentrate derived fiber in dairy cows. By Krämer et al., page 3163. Fiber is a major energy source in ruminant feedstuffs. New feed evaluation systems are based on passage and digestion rates but do not always account for intrinsic effects of forage type on passage kinetics. Effects of intrinsic feed characteristics and extrinsic ration characteristics on passage kinetics were analyzed with fecal marker excretion profiles and 
rumen evacuation. Treatments differed in forage type (corn silage, grass silage) and forage:concentrate ratio (50:50, 75:25). Intrinsic effects of forage type, rather than ration composition, determined the retention time of forage fiber in the total digestive tract. http://dx.doi.org/10.3168/jds.2012-6146.

Effects of feeding algal meal high in docosahexaenoic acid on feed intake, milk production, and methane emissions from dairy cows. By Moate et al., page 317\%. Thirty-two dairy cows were offered a basal diet of alfalafa hay and crushed wheat supplemented with different amounts of algal meal containing up to $75 \mathrm{~g}$ of docosahexaenoic acid (DHA)/cow per day. Addition of DHA did not affect total emissions of $\mathrm{CH}_{4}$ or emissions in terms of milk production, but $\mathrm{CH}_{4}$ emissions $/ \mathrm{kg}$ of dry matter intake were increased. Addition of DHA did not influence milk production, but milk fat concentration and yield of milk fat were decreased. Algal meal high in DHA is not an effective feed supplement to reduce $\mathrm{CH}_{4}$ emissions from dairy cows.

http://dx.doi.org/10.3168/jds.2012-6168.

Effect of calf starter feeding on gut microbial diversity and expression of genes involved in host immune responses and tight junctions in dairy calves during weaning transition. By Malmuthuge et al., page 3189. Calf starters are usually offered to dairy calves to facilitate the weaning process, but specific effects of solid feed consumption on gut health were not known. The present study revealed that solid feed consumption during weaning transition altered gut bacterial diversity and expression of host innate immune genes and tight junction genes of dairy calves. Observed differences in expression of genes related to mucosal innate immune responses and barrier functions in the calves fed with milk replacer and starter suggest that solid feed consumption may be associated with the development of mucosal functions in calves during the weaning process.

http://dx.doi.org/10.3168/jds.2012-6200.

Diurnal patterns of grazing behavior and humoral factors in supplemented dairy cows. By Sheahan et al., page 3201. Associations among humoral factors known to regulate intake in monogastric species and grazing behavior in the dairy cow were investigated. In the morning, the changes in humoral factors with grazing were consistent with those in monogastric species, with plasma ghrelin declining and insulin increasing with feed consumption. In comparison, during the major grazing bout before dusk, ghrelin and insulin concentrations both increased with feed consumption until sunset, contrary to the accepted negative effect of insulin and feed intake on ghrelin secretion. Humoral factors known to regulate hunger and satiety in mono- gastric species may have a role in the regulation of grazing behavior in dairy cows.

http://dx.doi.org/10.3168/jds.2012-6201.

Incremental effect of a calcium salt of cis-monounsaturated fatty acids supplement on milk fatty acid composition in cows fed maize silage-based diets. By Kliem et al., page 3211. Dairy cow supplements high in unsaturated fatty acids are effective at decreasing milk saturated fatty acid content, but often this is accompanied by increases in trans fatty acids. To minimize this, a calcium salt of cis-monounsaturated fatty acids supplement was fed to dairy cows in increasing amounts. The supplement substantially decreased saturated and increased cis-monounsaturated fatty acid concentrations in milk fat, without affecting milk yield. Trans fatty acids also increased, suggesting that rumen protection was not entirely complete. http://dx.doi.org/10.3168/jds.2012-6211.

Effects of rumen-protected $\gamma$-aminobutyric acid on feed intake, lactation performance, and antioxidative status in early lactating dairy cows. By Wang et al., page 3222. Feed intake by dairy cattle does not increase as rapidly as the increase of milk production in the early lactation stage. $\gamma$-Aminobutyric acid (GABA) has been shown to increase dry matter intake in lactating sows. Addition of rumen-protected GABA increased dry matter intake and net energy for lactation intake linearly and increased milk yield quadratically in early lactation dairy cows. Antioxidative status was improved by GABA supplementation. The optimal addition level of rumen-protected GABA was $0.8 \mathrm{~g} / \mathrm{d}$ for milk production.

http://dx.doi.org/10.3168/jds.2012-6285.

Effect of supplementing orchardgrass herbage with a total mixed ration or flaxseed on fermentation profile and bacterial protein synthesis in continuous culture. By Soder et al., page 3228. The aim of this study was to evaluate the effects of supplementing an herbage diet with a total mixed ration (TMR) or flaxseed on nutrient digestibility, fermentation profile, and bacterial nitrogen synthesis in a dual-flow continuous-culture fermentor system. Although TMR-based diets decreased nutrient digestibility slightly, TMR offered advantages in volatile fatty acid production, which could potentially translate into better animal performance. Flaxseed shows promise as an alternative supplement for herbage-based diets.

http://dx.doi.org/10.3168/jds.2012-6307.

Time-dependent variations in milk fatty acid composition after plant oil supplementation. By Martínez Marín et al., page 3238. Individual fatty acid content in milk fat starts to change soon after introducing plant oils into dairy goat diets. Most changes stabilize 
between 1 and $8 \mathrm{~d}$, reaching values found at the usual sampling times of $21 \mathrm{~d}$ or more in most experiments. When compared with values from an oil-free control diet, typical changes were observed for each of the 3 oils used: high oleic, regular sunflower, or linseed. These changes occurred between $1 \mathrm{~h}$ ( $\alpha$-linolenic acid, with linseed oil) and $5 \mathrm{~d}$ (medium-chain saturated fatty acids, with the 3 oils). Shorter sampling times could be used.

http://dx.doi.org/10.3168/jds.2012-6313.

Effect of feeding maternal colostrum, or plasma-derived or colostrum-derived colostrum replacer on passive transfer of immunity, health, and performance of preweaning heifer calves. By Priestley et al., page 324\%. Colostrum management and feeding is critical for calf health, future productive life, and farm profitability. The effect of feeding maternal colostrum (MC), a plasma-derived (PDCR), or a colostrum-derived (CDCR) colostrum replacer (CR) on passive transfer of immunity, health, and performance of preweaning heifer calves was evaluated. Preplanned contrasts were performed for MC compared with CR (PDCR combined with CDCR) and for PDCR compared with CDCR. Calves fed $3.8 \mathrm{~L}$ of $\mathrm{MC}$ had increased immunoglobulin $\mathrm{G}$ concentration, adequate passive transfer of immunity, weaning weights, and body weight gain, and decreased morbidity and mortality compared with calves fed 1 dose (100 or $150 \mathrm{~g}$ of immunoglobulin $\mathrm{G}$ ) of 2 commercially available CR. Calves fed CDCR had increased passive transfer of immunity and apparent efficiency of absorption compared with calves fed PDCR. Under the conditions of this trial, MC was superior to $\mathrm{CR}$.

http://dx.doi.org/10.3168/jds.2012-6339.

Effect of early exposure to mixed rations differing in forage particle size on feed sorting of dairy calves. By Miller-Cushon et al., page 325\%. The study objective was to determine how exposure during the milk-feeding stage to rations differing in forage particle size (coarsely chopped or finely ground) affects feed sorting of dairy calves after milk weaning, when all calves were offered the ration containing coarsely chopped hay. Calves previously exposed to the ration containing finely ground hay sorted in favor of concentrate and against hay to a greater extent than calves familiar with the coarsely chopped hay. Provision of a ration containing finely ground forage may increase feed sorting when feeding a ration containing large hay particles.

http://dx.doi.org/10.3168/jds.2012-6415.

Technical note: Evaluation of data loggers for measuring lying behavior in dairy calves. $B y$ Bonk et al., page 3265. Behavior provides valuable information about the well-being of an animal and its interaction with the environment. However, behavorial recordings are time consuming. Therefore, automated recording with the help of data loggers has become common in research and practice. Recently, a study showed that an acceleration data logger could be used to record lying behavior in dairy cows. We demonstrated that these loggers accurately measure total lying time and frequency of lying bouts in calves as well. http://dx.doi.org/10.3168/jds.2012-6003.

Effects of a national genomic preselection on international genetic evaluations. By Patry et al., page 327\%. Genomic selection is now widely implemented in dairy breeding schemes. This step needs to be included in the national genetic evaluations models to avoid biased BLUP (best linear unbiased predictor) evaluations sent to the Interbull Centre for international genetic evaluations. A genomic preselection step was simulated among young bulls and bias in international breeding values was assessed for traits measured in 3 countries. Young bulls retained by a genomic preselection were highly penalized. Their contemporaries from countries without genomic selection were also affected. Such biases led to nonoptimal rankings likely to affect selection decisions.

http://dx.doi.org/10.3168/jds.2011-4987.

Estimation of genetic parameters and detection of quantitative trait loci for metabolites in Danish Holstein milk. By Buitenhuis et al., page 3285. In this study, genetic parameters were estimated and quantitative trait loci (QTL) were detected for a detailed nuclear magnetic resonance (NMR)-based metabolite profile using 371 Danish Holstein milk samples. Heritabilities were in the range of 0 for lactic acid to $>0.8$ for orotic acid and $\beta$-hydroxybutyrate. A single nucleotide polymorphism association analysis revealed 7 genome-wide significant QTL. Selection to alter metabolites in bovine milk is possible.

http://dx.doi.org/10.3168/jds.2012-5914.

Understanding the genetics of survival in dairy cows. By Pritchard et al., page 3296. Improving survival of heifers during rearing and of milking cows is expected to have economic, health, welfare, and environmental benefits. Premature mortality and culling is a waste to the industry because a large number of heifers born never become productive or reach their full lactation potential. Presently, knowledge on the genetic component of heifer survival during the rearing period is sparse. However, cattle registration and movement data enable calculation of length of life and productive life, which allows alternative analyses of longevity, including survival before milk production commences. This study explores new methods to define longevity in dairy cows using national movement data for early life survival and productive life survival and shows that they are both heritable traits.

http://dx.doi.org/10.3168/jds.2012-6219. 
Genetic parameters for lameness and claw and leg diseases in dairy cows. By Weber et al., page 3310. The incidence of claw and leg diseases in dairy cows is a persistent welfare and economic issue in dairy production. A direct inspection of claws is expensive and time-intensive, but the related trait lameness recorded with a locomotion scoring system might be useful as a selection criterion to improve claw health. Therefore, genetic parameters were estimated applying both linear and threshold models. The genetic relationships among the traits were high and even increased from 0.60 to 0.72 after the exclusion of the claw disease digital dermatitis, which suggests that lameness seems to be a good indicator for claw and leg diseases. http://dx.doi.org/10.3168/jds.2012-6261.

Genetic parameters for hoof disorders and feet and leg conformation traits in Finnish Holstein cows. By Häggman and Juga, page 3319. Hoof and leg disorders are a major welfare problem in dairy farming. Although heritability for hoof health is low, longterm hoof health can be improved by genetic selection. Because feet and leg conformation traits are easier to evaluate and have higher heritabilities than hoof disorders, they could be used as indicator traits when breeding for better hoof health. In this study, 24,685 Holstein cows from 1,337 herds were used to estimate genetic parameters for hoof disorders and feet and leg conformation traits.

http://dx.doi.org/10.3168/jds.2012-6334.

Short communication: Genomic evaluations of final score for US Holsteins benefit from the inclusion of genotypes on cows. By Tsuruta et al., page 3332. Biases in genomic evaluations of final score were less for cows than for bulls. Reliability of bulls' genomic evaluations can be improved by using genotypes for cows in addition to genotypes for bulls.

http://dx.doi.org/10.3168/jds.2012-6272.

Short communication: Relationship of call rate and accuracy of single nucleotide polymorphism genotypes in dairy cattle. By Cooper et al., page 3336. Call rate is related to genotype accuracy on a single nucleotide polymorphism (SNP) and animal basis. For individual called SNP, an increase in missing SNP genotypes was associated with an increase in parentprogeny conflicts. For individual animals, percentage of detected parent-progeny conflicts increased when the call rate was $<80 \%$ for animals with genotyped sires or $<90 \%$ when both parents were genotyped because errors in the heterozygous SNP can be detected. For animals with 2 genotypes, concordance of $>99 \%$ was only found if the call rate was $>90 \%$. Edits on call rate reduce the use of incorrect SNP genotypes to calculate genomic evaluations.

http://dx.doi.org/10.3168/jds.2012-6208.
Production of an $18 \%$ protein liquid micellar casein concentrate with a long refrigerated shelf life. By Amelia and Barbano, page 3340. The goal of this study was to determine the feasibility of filtering skim milk to make a micellar casein concentrate that would have a long refrigerated shelf-life (i.e., $>12$ wk). The casein concentrate could be used as an alternative to making nonfat dry milk during a short-term surplus of skim milk in a region, while reducing hauling, concentration, and drying costs when balancing a milk supply. No increase in the bacterial count of $18 \%$ milk micellar casein concentrate stored at $4^{\circ} \mathrm{C}$ was detected over a period of $16 \mathrm{wk}$.

http://dx.doi.org/10.3168/jds.2012-6033.

Computer simulation of energy use, greenhouse gas emissions, and process economics of the fluid milk process. By Tomasula et al., page 3350. Greenhouse gas (GHG) emissions from fluid milk production may have significant environmental impact. Off-farm activities, such as milk processing, packaging, and cold storage contribute GHG emissions as energyrelated carbon dioxide $\left(\mathrm{CO}_{2}\right)$ emissions. A computer model was created that allows milk processors to test various changes in their plants to lower $\mathrm{CO}_{2}$ emissions, as well as to instantly calculate the energy cost savings and their equipment costs to implement the changes. The computer model will help the dairy industry realize its goal of reducing $\mathrm{CO}_{2}$ emissions by $25 \%$ per gallon of milk by the year 2020 . http://dx.doi.org/10.3168/jds.2012-6215.

Monitoring of Lactobacillus casei ATCC 393 survival in probiotic yogurts using an efficient molecular tool. By Sidira et al., page 3369. In the present study, survival of Lactobacillus casei ATCC 393 compared with Lactobacillus delbrueckii ssp. bulgaricus during refrigerated storage of probiotic yogurts was monitored by applying microbiological analysis and strain-specific multiplex PCR methodology. Both free and immobilized L. casei ATCC 393 of high industrial interest were detected in the novel products at levels $\geq 6 \log \mathrm{cfu} / \mathrm{g}$ (minimum level for probiotics) for periods longer than required by the dairy industry $(\geq 30 \mathrm{~d})$, in contrast to L. delbrueckii ssp. bulgaricus, in which the level decreased to $<6 \log \mathrm{cfu} / \mathrm{g}$ after $14 \mathrm{~d}$ of cold storage.

http://dx.doi.org/10.3168/jds.2012-6343.

A multivariate and stochastic approach to identify key variables to rank dairy farms on profitability. By Atzori et al., page 3378. This work aimed to find an empirical method to predict the profitability rank of dairy cattle farms of a specific area of production. The developed prediction index allowed us to (1) quantify the relative contribution of the most important technical and managerial aspects of each 
farm to its profitability, and (2) set up future targets of the production process within farms to increase the economic efficiency at the farm level. This proposed approach has potential application to other farms and production areas.

http://dx.doi.org/10.3168/jds.2012-6256.

Mineral concentrations in diets, water, and milk and their value in estimating on-farm excretion of manure minerals in lactating dairy cows. By Castillo et al., page 3388. Consumption of inadequate amounts of minerals by dairy cows can cause reduced animal performance. To prevent this, diets are often formulated to provide excess minerals, which increases excretion via manure. Accurate estimates of mineral excretion are needed for nutrient management plans. Mineral excretion is estimated using mass balance (dietary intake minus milk output). This study of 39 dairies determined that including mineral intake via water and assaying mineral concentrations of milk (rather than using table values) were necessary to avoid errors in estimating excretion of minerals (e.g., $\mathrm{Ca}, \mathrm{Na}, \mathrm{Cl}$, and $\mathrm{S}$ ).

http://dx.doi.org/10.3168/jds.2012-6121. 